\title{
Nutritional Value of Locally Available Plants with Potential for Diets of Tilapia Rendalli in Pond Aquaculture in NkhataBay, Malawi
}

\author{
Mzengereza $\mathrm{K}^{1 *}$, Msiska OV ${ }^{1}$, Kapute $\mathrm{F}^{1}$, Kang'ombe $\mathrm{J}^{2}$, Singini $\mathbf{W}^{1}$ and Kamangira $\mathrm{A}^{1}$ \\ ${ }^{1}$ Department of Fisheries Science, Mzuzu University, Private Bag 201, Mzuzu 2.Malawi \\ ${ }^{2}$ Department of Aquaculture and Fisheries Science, Lilongwe University of Agriculture and Natural Resources, Bunda College, P.O. Box 219, Lilongwe, Malawi
}

\begin{abstract}
Nutrient composition analysis was conducted for selected locally available plant based feedstuffs from Mpamba area in NkhataBay district of northern Malawi. The objective was to identify and isolate those that can be used as ingredients in the formulation of affordable and quality fish feeds to increase pond based fish production in Malawi. The following plant based feedstuffs were collected: Cassava (Manihot esculenta) peels (CP) and leaves (CL) Pawpaw (Carica papaya) leaves (PL), Sweet potato (Ipomea batatus) leaves, meal and tubers (SPL), (SPP) and (SPM) Jackfruit (Artocarpus heterophyllus) (JF), Mexican fireplant (MF) (Euphorbia heterophylla), Black jack (Bidens pilosa) (BJ), Banana (Musa balbisiana) leaves (BL), Maize (Zea maise) bran (MZB), and Akee (Blighia sapid) leaves (AK). Results showed that Cassava (Manihot esculenta) leaves, Black jack (Bidens pilosa) and Cocoyam (Caladium bicolor) leaves contain significantly high levels of crude protein: $21.17 \pm 0.56 \%, 24.35 \pm 0.7 \%$ and $24.28 \pm 0.11 \%$ respectively. Energy levels ranged from $29.7 \mathrm{kj} / \mathrm{g}$ to $8.78 \mathrm{kj} / \mathrm{g}$ for Sweet potato leaves and cassava peels respectively. In addition, all plant feedstuffs had low levels of crude fiber ranging from $3.78 \pm 0.20 \%$ to $16.84 \pm 0.26 \%$. Depending on their availability, potential, competition for other uses, crude protein, energy, crude fiber levels, most of the leaves analyzed demonstrated to be potential sources of fish feed. This suggests that while leaves have been utilized in low input aquaculture systems, they may serve as feeds for fish once the plant feedstuffs are appropriately incorporated in formulated diets and alternatively as organic fertilizers.
\end{abstract}

Keywords: Tilapia rendalli; Proximate composition; Plant feedstuffs; Aquaculture; Fish feed

\section{Introduction}

Nutrition is critical in fish production because feed represents $40-50 \%$ of the total variable costs [1]. Most small scale fish farmers in Malawi are not able to buy animal based fish feeds and legumes like fishmeal and soybean respectively, because they are expensive. This has negatively affected production and profitability of fish farming in Malawi. Access to nutritional inputs is identified as a key constraint by all fish farmers in Malawi [2]. Over $90 \%$ of all fish farmers use primarily maize bran (madeya) as fish feed. This feed ingredient has been recommended by extension services since the 1940s, but it has low protein content (10-11\%) and a poor food-conversion ratio (FCR) of 12-20:1 [3]. While the availability of maize bran is usually good, it can vary by region or season, and when there is a general shortage of maize (the Malawian food staple), maize bran faces competing uses as it is a major source of feed for livestock such as pigs and may be consumed directly by poorer families, hence not sustainable in production of fish feeds.

In Mpamba, aquaculture production is low and this is attributed to many reasons such unavailabity of a high quality affordable feed, lack of information in formulated fish feed preparation, inadequate extension services as well as slow growth of fish species currently being farmed in the area. Aside from issues of availability, evidence exists that farmers are still not fully aware of the benefits of using alternative inputs as composted maize stover, cassava leaves, sweet potato leaves, buffalo bean grass, antelope grass leaves, giant grass leaves, napier grass, mulberry leaves, Leucana leaves, banana leaves, pawpaw leaves, cabbage leaves, leftover homestead food such as nsima (traditional maize porridge) [4], and ash from kitchen fires [5], or of the importance of adhering to scheduled feeding times [4]. Apparently, use of fish meal as a protein source represents high cost of feed and the majority of small scale fish farmers in rural Malawian setting like Mpamba can hardly afford. In a quest to enhance aquaculture production which consequently improves food security, and reduce the level of poverty in developing countries, a search for affordable and locally available feedstuffs is being advocated [6].

Many locally available plants and plant-based products have been evaluated for inclusion in poultry and livestock feeds [7]. However, only a few have been evaluated for their potential use as Tilapia feeds [811]. In Malawi, several studies were conducted on the use of terrestrial plants for the production of Oreochromis shiranus and Tilapia rendalli and consumption ranged from $9-90 \%$ of plant dry matter per day; the best fish growth occurred in a 50:50 ratio registering 0.98 and 0.91 (\% per day) specific growth rate [12]. A similar study conducted by Chimatiro and Costa-Pierce [13] using cabbage, pumpkin leaves and maize bran recorded specific growth rates of 0.16 to 0.51 for cabbage and maize bran inputs. This shows that potential exists for using plant feed sources in Malawi aquaculture.

Development of a diet for fish production involves evaluation of proximate composition, digestibility and performance efficiency as well as cost implications and conditions for their application. It is from the foregoing that development of an affordable fish feed using locally available plant sources are imperative. It is important to focus on utilizing less expensive and readily available resources to replace fish

*Corresponding author: Mzengereza K, Department of Fisheries Science, Mzuzu University, Private Bag 201, Mzuzu 2.Malawi, Tel: +265 88899 8466; E-mail: kumbumzenge@yahoo.com

Received May 22, 2014; Accepted July 29, 2014; Published August 09, 2014

Citation: Mzengereza K, Msiska OV, Kapute F, Kang'ombe J, Singini W, et al (2014) Nutritional Value of Locally Available Plants with Potential for Diets of Tilapia Rendalli in Pond Aquaculture in NkhataBay, Malawi. J Aquac Res Development 5 265. doi:10.4172/2155-9546.1000265

Copyright: (c) 2014 Mzengereza K, et al. This is an open-access article distributed under the terms of the Creative Commons Attribution License, which permits unrestricted use, distribution, and reproduction in any medium, provided the original author and source are credited. 
meal, without reducing the nutritional quality of feed [14] as observed by Hecht and Maluwa [4] and Kang'ombe et al., [8] that use of available alternative ingredients would be sustainable in Malawi fish farming industry.

Mpamba area of NkhataBay district in northern Malawi is endowed with many locally available plants which are not usually consumed by mankind but may be of potential use in Tilapia feeds. Tilapia rendalli is one of the commercially important aquaculture species in Malawi and across tropical and subtropical countries. The present study, therefore, evaluated the nutritional potential of the different plant ingredients to be used as fish feed ingredients for Tilapia rendalli in Mpamba, northern Malawi The present study was undertaken to determine and evaluate the potential of selected locally available plants and plantbased products for use as ingredients in Tilapia diets. The justification of this work is that the targeted feedstuffs are locally available, found in abundance, affordable and are not directly consumed by humans. Therefore, it is envisaged that transformation of plant feedstuffs into high quality fish feed in low-input pond culture systems can make a significant contribution to improving fish production.

\section{Materials and Methods}

\section{Baseline study}

A study was conducted in Mpamba; Nkhata Bay in northern Malawi, to identify potential locally available plants and plant based feedstuffs which can incorporate into diets for pond raised fish. Selection of the feedstuffs was based on both temporal and spatial availability, abundance; competition for other uses and cost implications were also major factors.

\section{Collection of ingredients}

The following plant ingredients were collected: Cassava (Manihot esculenta) peels and leaves, Pawpaw (Carica papaya) leaves, Sweet potato (Ipomea batatus) leaves, meal and tubers, Jackfruit (Artocarpus heterophyllus), Mexican fireplant (Euphorbia heterophylla), Black jack (Bidens pilosa), Cocoyam (Colocasia esculenta) leaves, Banana (Musa balbisiana) leaves, Maize (Zea mais) bran, and Akee (Blighia sapid) leaves. The part of Cassava that were collected for analysis were leaves (CL) and peels (CP), Sweet potato peels (SPP), leaves (SPL) and tuber (SPM), whole Balck Jack (BJ), Banana leaves (BL), Pawpaw leaves (PPL), maize bran (MZB), Cococyum leaves (CYL), Mexican fire plant leaves (MFP), Jackfruit leaves (JK) and Akee leaves (AK)

\section{Processing of ingredients}

All ingredients were dried in the sun for 3 days to reduce their toxicity [15]. Drying of ingredients was done not only to reduce toxicity but also to mill them into powder form ready for proximate analysis. Ingredients were milled using a mortar and pestle. The ingredients were then sieved using a wooden sieve to remove cellulose and lignin materials to remain with the powder.

\section{Biochemical analyses}

The plant samples were analyzed for crude protein, crude fiber, ether extracts, ash and moisture content done in triplicate, following the procedure outlined by AOAC [16].

Dry matter (DM) was determined by drying 5 grams of sample in an oven for six hours to constant weight at $105^{\circ} \mathrm{C}$. Crude protein was quantified by the standard micro-Kjeldahl Nitrogen method, using a sample size of $0.4 \mathrm{~g}$ samples was determined by the acid digestion method of Furukawa and Tsukahara [17]. The distillate containing ammonia was trapped in $4 \%$ boric acid solution prior to titration with $0.1 \mathrm{~N} \mathrm{HCl}$. Crude protein was estimated by multiplying the nitrogen content with a factor of 6.25 as used by Kopruco [18]. Ether extracts were analyzed using a sample size of $2 \mathrm{~g}$ in a soxhlet extractor with petroleum ether (boiling point $40-60^{\circ} \mathrm{C}$ ). Crude fiber $(\mathrm{CF})$ was determined by boiling $1 \mathrm{~g}$ of sample in a standard solution of $3.13 \%$ $\mathrm{H}_{2} \mathrm{SO}_{4}$ for 10 minutes. The remaining sample was rinsed with hot water followed by boiling in $3.13 \% \mathrm{NaOH}$ for another 10 minutes. Thereafter, the remaining sample was rinsed repeatedly with hot water followed by acetone. The residue was oven dried at $60^{\circ} \mathrm{C}$ for 4 hours, cooled in desiccators and weighed. The residue was ashed at $550^{\circ} \mathrm{C}$ in a muffle furnace overnight as was with Mach et al. [19]. CF was quantified by expressing the loss in weight after ashing as a percentage of the original weight of the sample. Nitrogen Free Extracts were estimated by difference (DM-CP-EE-CF-Ash) and this was consistent with Borghesi et al. [20].

\section{Statistical analysis}

One way Analysis of variance (ANOVA) was used to analyze proximate and mineral content data run in SPSS for windows version 16.0. The significant differences were considered at 5\% where the Duncan's Multiple Range Test was used to separate significantly different means.

\section{Results}

Data on proximate composition of selected plant feedstuffs are presented in Tables 1 and 2.

All the ingredients in each component analyzed were sigficantly different from each other at $(\mathrm{P}>0.05)$. Multiple comparions done using Duncans test revealed that protein was highest in Black jack, cocoyam and cassava leaf as these were statistically not different from each other. Energy was highest in sweet potato meals and leaf and also maize bran.

However, big variations were observed in calcium levels between Sweet potato (Ipomoea batatus) leaf and Sweet potato (Ipomoea batatus) peel had $19.05 \%$ and $14.08 \%$ respectively, and Banana (Musa acuminate) leaf meal which recorded $0.03 \% .1$.

\section{Discussion}

\section{Crude protein}

In the present study, Cassava Leaf Meal (CLM) and Cassava peels recorded $21.17 \%$ and $5.33 \%$ Crude Protein level (CP) respectively. Iheukwumere et al. [21] reported $25.10 \%$ while Ekenam et al. [22] reported $25 \%$ crude protein for cassava leaf meal both which conform to the present study. Kango'mbe et al. [8] reported $14.07 \%$ CP and $7.28 \%$ CP on Cassava leaf meal and peels respectively which are lower than those in the present study. Previous studies conducted indicate that all the experimental diets were accepted by fish; therefore, Cassava leaf meal in fish diets did not have adverse effect on the palatability of experimental diets [22]. These results were in agreement with those found by Omeregie et al. [23] who included cassava peelings and mango seeds in the diet of Oreochromis niloticus. Cassava has been successfully used to replace maize bran in Clarias gariepinus fingerling and advanced fry [24]. Cassava leaf and peel can be used to cut down the cost of production and lead to an active and sustainable development in fish production. Cassava, one of the world top calorie producers, is generally grown without fertilization on soils with poor fertility and can survive prolonged water deficit, it tolerates acid soils, but the yield is limited by poor phosphorus supply. 
Citation: Mzengereza K, Msiska OV, Kapute F, Kang'ombe J, Singini W, et al. (2014) Nutritional Value of Locally Available Plants with Potential for Diets of Tilapia Rendalli in Pond Aquaculture in NkhataBay, Malawi. J Aquac Res Development 5: 265. doi:10.4172/2155-9546.1000265

Page 3 of 6

\begin{tabular}{|c|c|c|c|c|c|c|}
\hline Ingredient Analyzed & Moisture & Ash & Fiber & Protein & Fat & Energy $\mathrm{Kj} / \mathrm{g}$ \\
\hline $\mathrm{CL}$ & $11.97 \pm 0.75^{a}$ & $13.6 \pm 0.65^{b}$ & $16.35 \pm 0.75^{a}$ & $21.17 \pm 0.56^{a}$ & $3.16 \pm 0.00^{b}$ & 20.59 \\
\hline $\mathrm{CP}$ & $6.70 \pm 0.09^{b}$ & $46.6 \pm 0.40^{c}$ & $16.84 \pm 0.26^{a}$ & $7.40 \pm 0.34^{b}$ & $5.92 \pm 0.1^{b}$ & 8.78 \\
\hline SPL & $10.89 \pm 0.31^{a}$ & $85.75 \pm 0.0^{\mathrm{a}}$ & $9.16 \pm 0.70^{c}$ & $8.40 \pm 0.10^{c}$ & $2.98 \pm 0.25^{b}$ & 29.7 \\
\hline SPP & $25.95 \pm 4.29^{c}$ & $6.04 \pm 0.45^{b}$ & $3.26 \pm 0.20^{\mathrm{b}}$ & $8.40 \pm 0.80^{c}$ & $5.01 \pm 1.64^{b}$ & 15.21 \\
\hline CYL & $7.08 \pm 1.56^{\mathrm{a}}$ & $14.84 \pm 0.45^{b}$ & $3.95 \pm 0.15^{b}$ & $24.28 \pm 0.11^{\mathrm{d}}$ & $7.23 \pm 1.52^{c}$ & 19.54 \\
\hline $\mathrm{BL}$ & $7.80 \pm 1.56^{\mathrm{a}}$ & $16.8 \pm 3.50^{b}$ & $6.95 \pm 0.15^{b}$ & $7.65 \pm 0.23^{b}$ & $2.22 \pm 0.10^{\mathrm{b}}$ & 19.06 \\
\hline PPL & $10.95 \pm 0.10^{\mathrm{a}}$ & $13.5 \pm 0.47^{b}$ & $5.50 \pm 0.20^{\mathrm{b}}$ & $2.78 \pm 0.14^{\mathrm{e}}$ & $16.07 \pm 0.10^{\mathrm{a}}$ & 15.21 \\
\hline BJ & $20.79 \pm 0.71^{d}$ & $23.1 \pm 0.91^{c}$ & $6.40 \pm 0.75^{b}$ & $24.35 \pm 0.7^{d}$ & $5.65 \pm 0.93^{b}$ & 12.4 \\
\hline MZB & $8.87 \pm 0.90^{a}$ & $3.72 \pm 0.32^{b}$ & $3.40 \pm 0.15^{b}$ & $11.81 \pm 0.11^{\mathrm{c}}$ & $7.28 \pm 1.90^{\circ}$ & 15.72 \\
\hline MFP & $10.05 \pm 1.00^{\mathrm{a}}$ & $11.9 \pm 0.21^{b}$ & $6.35 \pm 0.25^{b}$ & $11.40 \pm 0.11^{c}$ & $4.64 \pm 1.49^{b}$ & 12.22 \\
\hline AK & $10.37 \pm 0.43^{a}$ & $7.06 \pm 0.05^{\mathrm{b}}$ & $5.5 \pm 0.35^{b}$ & $12.07 \pm 0.18^{c}$ & $10.58 \pm 1.00^{c}$ & 19.63 \\
\hline JF & $8.44 \pm 0.20^{\mathrm{a}}$ & $9.05 \pm 0.15^{b}$ & $7.0 \pm 0.20^{b}$ & $4.77 \pm 0.45^{b}$ & $7.83 \pm 0.25^{c}$ & 19.27 \\
\hline SPM & $9.67 \pm 0.11^{\mathrm{a}}$ & $85.7 \pm 0.15^{a}$ & $3.19 \pm 0.30^{b}$ & $11.97 \pm 0.45^{c}$ & $3.2 \pm 0.45^{b}$ & 15.32 \\
\hline
\end{tabular}

Table 1: Proximate composition of plant ingredients from Mpamba (Mean \pm SE) expressed as percent (\%) dry matter.

Values (Mean $\pm \mathrm{SE}$ ) in a column with different superscript letters are significantly different $(\mathrm{P}<0.05)$; Where; CL: Cassava Leaf, CP: Cassava Peels, SML: Sweet Potato Meal, SPP: Sweet Potato Peel, CYL: Cocoa yam, BL: Banana Leaf, PPL: Papaya Leaf Meal, BJ: Black Jack, MZB: Maize Bran, MFP: Mexican fireplant, AK: Akee, JF: Jackfruit, SPM: Sweet potato meal.

\begin{tabular}{|c|c|c|c|c|}
\hline Ingredient Analyzed & Calcium & Potassium & Phosphorus & Vitamin C \\
\hline CL & $1.62 \pm 0.04^{\mathrm{c}}$ & $1.11 \pm 0.01^{\mathrm{a}}$ & $0.29 \pm 0.02^{\mathrm{a}}$ & $5.55 \pm 0.75^{\mathrm{a}}$ \\
\hline CP & $0.57 \pm 0.02^{\mathrm{c}}$ & $0.89 \pm 0.01^{\mathrm{a}}$ & $0.12 \pm 0.01^{\mathrm{a}}$ & $3.63 \pm 0.15^{\mathrm{a}}$ \\
\hline SPL & $21.1 \pm 0.29^{\mathrm{a}}$ & $1.33 \pm 0.01^{\mathrm{a}}$ & $0.88 \pm 0.03^{\mathrm{a}}$ & $12.3 \pm 0.05^{\mathrm{b}}$ \\
\hline SPP & $14.8 \pm 0.12^{\mathrm{d}}$ & $0.98 \pm 0.01^{\mathrm{a}}$ & $14.8 \pm 0.12^{\mathrm{b}}$ & $4.75 \pm 0.15^{\mathrm{c}}$ \\
\hline CYL & $0.23 \pm 0.10^{\mathrm{c}}$ & $0.19 \pm 0.02^{\mathrm{c}}$ & $0.55 \pm 0.00^{\mathrm{a}}$ & $12.4 \pm 0.15^{\mathrm{b}}$ \\
\hline BL & $0.33 \pm 0.00^{\mathrm{c}}$ & $0.26 \pm 0.23^{\mathrm{c}}$ & $0.12 \pm 0.00^{\mathrm{a}}$ & $3.00 \pm 0.20^{\mathrm{a}}$ \\
\hline PPL & $1.05 \pm 0.05^{\mathrm{d}}$ & $0.89 \pm 0.01^{\mathrm{a}}$ & $2.23 \pm 0.04^{\mathrm{a}}$ & $21.2 \pm 0.15^{\mathrm{d}}$ \\
\hline BJ & $4.66 \pm 0.00^{\mathrm{d}}$ & $2.20 \pm 0.14^{\mathrm{b}}$ & $7.01 \pm 0.00^{\mathrm{c}}$ & $5.07 \pm 0.75^{\mathrm{a}}$ \\
\hline MZB & $0.55 \pm 0.01^{\mathrm{c}}$ & $0.33 \pm 0.00^{\mathrm{c}}$ & $0.56 \pm 0.02^{\mathrm{a}}$ & $1.30 \pm 0.00^{\mathrm{a}}$ \\
\hline MFP & $2.80 \pm 0.00^{\mathrm{e}}$ & $1.70 \pm 0.00^{\mathrm{a}}$ & $5.30 \pm 0.10^{\mathrm{a}}$ & $13.7 \pm 5.15^{\mathrm{b}}$ \\
\hline AK & $2.30 \pm 0.06^{\mathrm{e}}$ & $1.48 \pm 0.14^{\mathrm{a}}$ & $4.02 \pm 0.01^{\mathrm{a}}$ & $13.7 \pm 0.00^{\mathrm{b}}$ \\
\hline JF & $3.33 \pm 0.03^{\mathrm{e}}$ & $2.60 \pm 0.25^{\mathrm{d}}$ & $2.44 \pm 0.38^{\mathrm{a}}$ & $12.6 \pm 0.20^{\mathrm{b}}$ \\
\hline SPM & $19.0 \pm 0.16^{\mathrm{b}}$ & $1.64 \pm 0.00^{\mathrm{e}}$ & $1.04 \pm 0.06^{\mathrm{a}}$ & $2.80 \pm 0.00^{\mathrm{c}}$ \\
\hline
\end{tabular}

Table 2: Mineral composition of plant ingredients from (Mean \pm SE) Mpamba expressed as percentage (\%) dry matter.

Values (Mean $\pm \mathrm{SE}$ ) in a column with different superscript letters are significantly different $(P<0.05)$; Where; $C L$ : Cassava Leaf, $C P$ : Cassava Peels, SML: Sweet Potato Meal, SPP: Sweet Potato Peel, CYL: Cocoa yam, BL: Banana Leaf, PPL: Papaya Leaf Meal, BJ: Black Jack, MZB: Maize Bran, MFP: Mexican fireplant, AK: Akee, JF: Jackfruit, SPM: Sweet potato meal.

The nutritional limitations of cassava leave, however, include the cyanide content, low digestible energy, bulkiness and possibly the high tannin content. The inherent cyanogenetic glycosides may limit its use as fish feed. The cyanogenetic glycosides, is influenced by the nutritional status and age of the plant where cyanide content decreases with the maturity of the leaves. Therefore, use of relatively mature leaf meal can avoid running the risk compromising growth and survival of the fish. In addition processing methods can reduce the cyanogenic effects. The two most widely used processing methods are sun drying and ensiling. Sun drying must be done thoroughly especially in the wet season because it may result in the production of low quality product with severe Aspergillus and aflatoaxin contamination if the moisture has not been gotten rid of. Ensiling the leaves entails chopping into small pieces (average of $2 \mathrm{~cm}$ ), add additives and add common salt at $0.5 \%$ and store in sealed air tight plastic bags for two months could reduce cyanide content up to $90 \%$ of the original concentrations. Cassava leaf contains high level of crude protein, vitamins and nutritionally valuable minerals .Although Cassava leaf protein is deficient in methionine, possibly marginal in tryptophan, it is rich in lysine which is necessary in skeletal and skin formation and also improves the body immune system by production of antibodies.
Sweet potato leaf meal and Sweet potato peels registered $11.17 \%$ and $8.4 \%$ crude protein contents respectively which are lower than $23.57 \%$ reported by Adewulo [15] and 14.59\% reported by Kang'ombe [8]. However, Sweet potato leaf meal has potential for use as a protein source in Tilapia zilli diet up to $15 \%$ level without compromising growth performance [23]. Expanded use of sweet potato as animal feed appears to be promising for both agro-biological and socio-economic reasons. Sweet potato is widely adapted to diverse altitudes (up to $2000 \mathrm{~m}$ ) and temperature conditions. It requires practically no cash inputs and minimal horticultural practices. According to Ishida et al the above-ground parts of sweet potato, such as leaves, stalks and stems have a high nutritive value. In particular, leaves contain a large amount of protein with a high amino acid score [25]. Contents of minerals and vitamins such as $\mathrm{A}, \mathrm{B}_{2}, \mathrm{C}$ and $\mathrm{E}$ are high in leaves in comparison with other vegetables. For this reason, both roots and vines are used as a protein and vitamin source for fish and livestock [26].

Pawpaw recorded $2.23 \%$ crude protein which is lower than that reported by other workers. For instance, Onyimonyi and Ernest [27] reported crude protein value of $30.12 \%$ for pawpaw leaf meal (PLM), $17.3 \%$ crude protein value reported by Esonu et al. [28] and $9.45 \%$ by Kang'ombe et al. [8]. Papaya leaves may be a valuable feed component in Tilapia production systems, which are based on local resources, due to their high protein content and proteolytic properties [6]. Pawpaw leaves incorporated at $2 \%$ level in the diets of Tilapias and improves growth performance, carcass and organoleptic indices [27]. In addition, the pawpaw plant is high in vitamins $\left(\mathrm{A}, \mathrm{B}_{1}, \mathrm{~B}_{2}\right.$ and $\left.\mathrm{C}\right)$ and minerals (Ca, K, P, and $\mathrm{Fe}$ ) [29]. Furthermore, pawpaw contain papain which aids digestion thereby releases free amino acids which enhances growth $[27,30]$. Other studies indicate that Papaya carica leaf meal could be a good protein source because of its amino acid profile [31].

Cocoyam registered $24.28 \%$ and $19.54 \mathrm{Kg} / \mathrm{J}$ values for crude protein and energy levels. Similarly, Zaid and Sogbeasan [32] reported 5.19\% and $88.4 \%$ for crude protein and energy levels. There is therefore, superiority in energy levels suggesting the use of tannia Cocoyam as energy in fish and livestock production. Cocoyam (Xanthosoma sagittifolium) is non-conventional feedstuff recognized as cheaper and easily digestible carbohydrate sources than grains or other tuber crops. In addition, it has high caloric yield per hectare, low production cost and relatively low susceptibility to insect and pest attack [33]. It is almost competition-free with man in most places as it is eaten as a last 
Citation: Mzengereza K, Msiska OV, Kapute F, Kang'ombe J, Singini W, et al. (2014) Nutritional Value of Locally Available Plants with Potential for Diets of Tilapia Rendalli in Pond Aquaculture in NkhataBay, Malawi. J Aquac Res Development 5: 265. doi:10.4172/2155-9546.1000265

resort. However, $10 \%$ cocoyam inclusion level is the best in terms of daily weight gain feed conversion ratio and cost effectiveness.

In the present study Black jack (Bidens pilosa) registered $24.3 \%$ crude protein, $12.4 \mathrm{kj} / \mathrm{g}$ energy, $23.1 \%$ ash, $4.66 \%$ Calcium, $2.20 \%$ Phosphorus and 7.0\% Pottassium. Elsewhere, Alikwe et al. [34] reported that Black Jack (Bidens pilosa) leafmeal (BPLM) had Crude Protein of $15.86 \%$, ash $12.31 \%$ Calcium $0.39 \%$, Phosphorus $0.31 \%$ and Potassium $1.21 \%$, Methionine $0.54 \%$ and, Lysine $1.07 \%$ among others. The high protein $(24.3 \%)$ level of Black jack (Bidens pilosa) and the presence of methionine and lysine amino acids reported in previous study is an indication of the potential for inclusion in animal diet as a protein source. Secondly, the high ash (23.1\%) level is an indication of a good mineral profile in Black Jack (Bidens pilosa). The ash content is a reflection of the mineral contents preserved in the food materials. The results, therefore, suggests a moderate deposit of mineral elements in the leaves [35]. Thus, Bidens pilosa is a potential plant protein coupled by good mineral presence that can reduce the cost of production which is accelerated by use of animal protein among other reasons. From the foregoing, cassava leaf, cocoyam leaf and black jack combination in a diet would be advocated as possible sources of protein in diet.

\section{Crude fibre}

Cassava leaf meal and cassava peels registered $16.35 \%$ and $16.86 \%$ fiber respectively. In a study by Adewulo [15], sweet potato leaf meal exhibited fiber content of $8.2 \%$ whilst Ebowei and Ekubo, found 11.5\% fiber content in Sweet potato leaf meal and Kang'ombe et al. [8] reported $4.94 \%$ fiber content for sweet potato leaf meal in Chingale, Southern Malawi. However, in the present study crude fiber content in sweet potato leaf meal was 3.19\% which was lower than those in the studies referred to. Crude fiber content for Papaya leaf meal was 5.6\% [27], 5.99\% was reported by Kang'ombe et al. [8] and both results are in agreement with the current study which recorded 5.5\%. On the other hand, crude fiber level for Cocoyam leaf meal reported by Kang'ombe et al. [8] was $5.10 \%$ and that by Onyimonyi and Ernest [27] was $8.8 \%$ both of which were higher than that of this study which was $3.96 \%$. The crude fiber content for Black jack in this study was $6.45 \%$ which is very close to $6.84 \%$ that Kang'ombe et al. [8] reported. Finally, crude fiber contents for Jackfruit (7\%), Mexican fireplant (6.35\%) and Akee (5.5\%) are in any case considered moderate for inclusion in fish diets. High crude fiber levels do not only impede digestibility of diets but also jeopardize the binding capacity of the feed. This is reflected by poor diet utilization caused by poor binding ability of the feed due to high crude fiber content of CLM which causes it to scatter in water. In the current study the level of fiber was somewhat moderate in most plant feedstuffs and can be digested by Tilapia rendalli which is itself a herbivorous macrophyte feeder.

\section{Gross energy}

The amount of energy for most plant feedstuffs in this study were in agreement with those reported by other authors. Kang'ombe et al. [8] reported the following energy contents: Cassava leaf meal $(12.95 \mathrm{kj} / \mathrm{g})$, Black jack (kj/g), and Banana leaf meal (kj/g) whilst Cocoyam leaf meal and Papaya leaf meal pegged at $(\mathrm{kj} / \mathrm{g})$. In other previous studies, [27] found Energy contents for Cassava leaf meal $(14.3 \mathrm{kj} / \mathrm{g})$, Sweet potato leaf meal (12.5 kj/g) Pawpaw leaf (kg/j) and Cocoyam leaf $(33.18 \mathrm{kj} / \mathrm{g})$. This study, however, found the following energy contents cassava leaf meal $(20.59 \mathrm{kj} / \mathrm{g})$, Sweet potato leaf $(15.34 \mathrm{kj} / \mathrm{g})$, Papaya leaf $(15.21$ $\mathrm{kj} / \mathrm{g})$, Banana leaf meal $(\mathrm{kj} / \mathrm{g})$, Maize bran $(10 \mathrm{kj} / \mathrm{g})$ and Cocoyam leaf meal $(19.54 \mathrm{kj} / \mathrm{g})$. These energy levels entail that incorporation of plant feedstuffs investigated this study in the diet they would be have a protein sparing effect where the fish will not need to convert some the protein for energy. Sweet potato tuber meal and leaf meal could form a formidable energy source combination in diet due to their superiority levels and their incorporation would help pare protein for somatic growth.

\section{Ash and minerals}

Ash content in this study had a big variation amongst ingredients ranging from a high $85.75 \%$ to a lowest $3.72 \%$ for Sweet potato leaf meal and Maize bran respectively. In a study by Kang'ombe et al. [8], the ash contents were $6.64 \%$ for cassava leaf meal, $6.48 \%$ for sweet potato leaf meal, $6.49 \%$ for Cocoyam leaf meal, $7.27 \%$ for Banana leaf meal and $5.54 \%$ and $6.59 \%$ for pawpaw leaf meal and black jack meal respectively. It has been found that the concentration of minerals was proportional to the ash content in plant materials like aquatic weeds, sweet potato and cassava leaves, guinea and Napier grasses [36]. Therefore, the intake of these plant feedstuffs could contribute to a large proportion of calcium, phosphorus and iron requirement of fish when they are used as supplementary feed in the fish ponds as well as in low cost formulated feed in semi-intensive aquaculture systems like ponds [36]. In addition, where vitamin and mineral premixes are not incorporated especially in rural communities like Mpamba, the use of plant feedstuffs would assist in formulation of less costly feeds which is at the same time nutritionally sound. Moisture content of pawpaw leaf meal in this study was $10.95 \%$ and this corresponds to those reported by Onyimonyi and Ernest [27] who found $10.20 \%$ whilst Kang'ombe et al. [8] reported $48 \%$ moisture content for pawpaw leaf meal.

\section{Crude fat}

The crude fat levels in the present study ranged from $2.22 \%$ to $16.07 \%$ (Table 1). Kang'ombe et al. [8] reported $2.56 \%$ crude fat level for Cocoyam, $0.01 \%$ for PPM, $0.12 \%$ and $1.0 \%$ for Cassava leaf meal and Black jack respectively. In other studies by Abowei and Ekubo [37] the crude fat content reported were $1.0 \%$ for Cassava leaf meal, $3 \%$ for Sweet potato leaf meal which is also similar to that reported by Adewulo [15], 0.8\% for Pawpaw leaf meal just to mention but a few. It is evident from the results that fat content for most ingredients in this study were higher than those observed in other studies. Commercial Tilapia feeds for grow out usually contain 5 to $6 \%$ total lipid, but high lipid levels of 10 to $12 \%$ are used in diets containing higher protein [38]. Therefore, the crude fat contents of ingredients analyzed in this study are within the allowable range and can easily be used in Tilapia diets. Fat is important in provision of energy and helps in protein sparing thereby allowing protein deposition for somatic growth.

The differences in the proximate compositions could be attributed to different processing techniques, variations in climate, strain of the plant species and soil chemistry [39]. In addition, [27] reported that disparity in nutritive value of plants may be attributed to differences in environmental conditions, such as soil chemistry, harvesting method, ingredients varieties and temperature.

\section{Conclusion}

The potential of feedstuffs such as leaf meal in fish diets can be evaluated on the basis of its proximate chemical composition, comprising the moisture content, crude protein, crude fiber, crude lipid, total ash and nitrogen-free extract. Results of the present study confirmed that the crude protein content of feedstuffs from plant origin was lower than that of most animal by-products. Nevertheless, the costs of feed components from animal origin are generally high and 
Citation: Mzengereza K, Msiska OV, Kapute F, Kang'ombe J, Singini W, et al. (2014) Nutritional Value of Locally Available Plants with Potential for Diets of Tilapia Rendalli in Pond Aquaculture in NkhataBay, Malawi. J Aquac Res Development 5: 265. doi:10.4172/2155-9546.1000265

Page 5 of 6

therefore those from plants are unlikely to be cost-effective for semiintensive tilapia production systems.

\section{Recommendation}

It has been observed from the study that most nutrient levels in the selected plant feedstuffs are ideal for the requirements of Tilapias. Therefore, the study recommends inclusion of plant feedstuffs in Tilapia diets in order to minimize the cost of fish production among small scale fish farmers. However, before wholesale utilization of plant feedstuffs in fish diets, there is also need for further research to evaluate among others, the amino acid profile, digestibility and anti-nutritional factors of the plant feedstuffs.

\section{Acknowledgement}

The authors wish to thank the Regional Universities Forum for Capacity Building in Agriculture (RUFORUM), for financial support. Department of Aquaculture and Fisheries Science at Lilongwe University of Agriculture and Natural Resources (LUANAR) are acknowledged for providing laboratory support. Special thanks are expressed to Mr. Elton Nyali for laboratory analysis.

\section{References}

1. Craig S, Helfrich LA (2002) Understanding Fish Nutrition, Feeds and Feeding. Cooperative Extension Service, Virginia State University, USA, 420-256.

2. Andrew TG, Weyl OLF, Andrew M (2003) Aquaculture master plan development in Malawi. Soci-economic survey report.

3. Hecht T (1999) Border Zone Aquaculture Development Project and NARMAP Fisheries Management Project, backstopping report 1 for 1999. Department Ichthyology and Fisheries Science, Rhodes University, Grahamstown, South Africa.

4. Hecht T, Maluwa A(2004) Situation analysis of aquaculture in Malawi. Environ fish Africa (Pty) Ltd, Grahamstown, South Africa, and National Aquaculture Centre, Domasi, Malawi.

5. Jamu D, Costa-Pierce BA (1993) Use of firewood ash in small scale aquaculture Journal of Aquaculture in the Tropics 8: 167-175.

6. Munguti JM, Liti DM, Waidbacher H, Straif M,Zollitsch W (2006) Proximate composition of selected potential feedstuffs for Nile tilapia (Oreochromisniloticus Linnaeus) production in Kenya. Die Bodenkultur 57: 131-141.

7. Gomez M (1982) Nutritional Characteristics of Some Selected NonConventional Feedstuffs: Their Acceptability, Improvement and Potential Use in Poultry Feeds. Animal Feed and Technology 36: 143-152.

8. Kang'ombe J, Kapute F,Ntenjera G (2009) Nutrient analysis of locally available plant based feed ingredients used by Chingale farmers and their potential for fish feed development in pond raised improved strain of Oreochromisshiranus. ARDEP Dissemination Seminar 2009, Malawi 15-18.

9. Liti D, Mugo MR, Munguti MJ, Waidbacher H (2006) Growth and economic performance of Nile tilapia (Oreochromisniloticus L.) fed on three brans (maize wheat and rice) in fertilized ponds. Aquaculture Nutrition 12: 239-245.

10. Liti D, Kerogo L, Munguti JM,Chhorn L (2005) Growth and economic performance of Nile tilapia (Oreochromisniloticus L.) fed on two formulated diets and two locally available feeds in fertilized ponds. Aquaculture Research 36: 746-752.

11. Maina JG, Beames RM, Higgs D, Mbugua PN, Iwama G, et al. (2002) Digestibility and feeding value of same feed ingredients fed to tilapia Oreochromisniloticus(L). Aquaculture Research 33: 853-862.

12. Chikafumbwa FJK (1996) Use of terrestrial plants in aquaculture in Malawi The Third International Symposium on Tilapia in Aquaculture Conference Proceedings 41: 175-182.

13. Chimatiro SK, Costa-Pierce BA (1996) Waste vegetable leaves as feeds for juvenile Oreochromisshiranus and Tilapia rendalli in mono-and polyculture. The Third International Symposium on Tilapia in Aquaculture Conference Proceedings 41: 183-192.

14. El-Sayed AM (1999) Alternative dietary protein sources for farmed tilapia, Oreochromiss spp. Aquaculture. 179: 149-168.

15. Adewolu MA (2008) Potentials of Sweet Potato (Ipomoea batatas) Leaf Mea as Dietary Ingredient for Tilapia zilli fingerlings. Pakistan Journal of Nutrition 7: $444-449$.

16. AOAC (2000) Official Methods of Analysis. (15thedn). Association of Officia Analytical Chemists. Washington, DC, USA

17. Furukawa A, Tsukahara $\mathrm{H}$ (1966) On the acid digestion of chromic oxide as an index substance in the study of digestibility of fish feed. Bull Jpn Soc Sci Fish 32: 502-508.

18. Koprucu K (2012) Variability in the chemical composition of different cotton seed and sunflower meals influence their digestibility when fed to grass carp (ctenopharyngodonidella). Aquaculture research 18: 666-672.

19. Mach DTN, Nguyen MD, Nortvedt R (2010) Effect of digestibility and growth on afevant cobia (Recycentoncanadum) fed fish or crab silage protein. Aquaculture research 16: 305-312.

20. Borghesi R, Dairiki JK, Cyrino JEP (2009) Apparent Digestibilty coefficient of selected feed ingredients for douradoSalminusbransiliensis.Aquaculture research 15: 453-458.

21. Iheukwumere FC, Ndubuisi EC, Mazi EA, Onyekwere MU (2008) Performance, nutrient utilization and organ characteristics of broilers fed cassava leaf meal (Manihotesculenta Crantz). Pakistan Journal of Nutrition 7:13-16.

22. Ekanem AP, Eyo VO, Ndome CB (2010) The Effect of diet with different inclusion level of Cassava leaf meal (CLM) Mahinot utilization on the growth performance of Heteroclarias fingerings. Journal of Sciences and Multidisciplinary Research 2: 58-67.

23. Omoregie E, Igoche L, Ojobe TO, Absalom KV, Onusiriuka BC (2009) Effect of varying Levels of Sweet potato (Ipomeabatatas) Peels of Sweet Potato on, Fedd utilization and some Biochemical Responses of cichlid (Oreochromisniloticus) African Journal of Food Agriculture Nutrition and Development 9: 700-712.

24. Abu OMG, Gabriel, Akinrotimi OA (2010) Performance and survival of hybrid catfish (Hetero $X$ Clarias) fed with whole cassava root meal as a replacemen for maize.Journal of Tropical Agriculture Environment and Extension 9: 176 $-183$.

25. Ishida H, Suzuno H, Sugiyama N, Innami S, Tadokoro T, et al. (2000) Nutritive value on chemical components of leaves stalks and stems of sweet potato (Ipomoea batatasPoir). Food Chemistry 68: 359-367.

26. Ali MA, Tageldin TH, Solaiman EM (1999) Effect of sweet potato tops or roots in growing rabbit diets on growth performance, digestibility, carcass traits and economic efficiency. Egyptian Journal of Rabbit Sciences 9: 13-23.

27. Onyimonyi AE, Ernest $O$ (2009) An Assessment of Pawpaw Leaf Meal as Protein Ingredient for Finishing Broiler. International Journal of Poultry Science 8: 995-998.

28. Esonu BO, Iheukwumere FC, Emenalom OO, Uchegbu MC, Etuk EB (2002) Performance, nutrient utilization and organ characteristics of broilers fed Microdesmispuberula leaf meal. Livestock for rural development 14: 6-10.

29. Yadava UL, Janice A, Burris, McGary D (1990) Papaya: A Potential annual crop under middle Georgia conditions. In: J. Janick and J.E. Simons Edn. Advances in New Crops. Timber Press, Portland, 364-366.

30. Chaplin M (2005) Application of proteases in the food industry. Faculty of Engineering Science and the build environment, South bank University Press. London, UK.

31. Reyes OS, Fremin AC (2003) Terrestrial leaf meals or freshwater aquatic fern as potential feed ingredients for farmed abalone Haliotis asinine (Linnaeus 1758). Aquaculture Research 34: 593-599.

32. Zaid AA, Sogbesan OA (2010) Evaluation and potential of Cocoyam as carbohydrate source in catfish, (Clarias gariepinus) juvenile diets. African Journal of Agricultural Research 5: 453-457.

33. Abdulrashid M, Agwunobi LN (2012) Tannia (Xanthosoma sagittifolium) Cocoyam as Dietary Substitute for Maize in Broiler Chicken. Greener Journal of Agricultural Sciences 2: 167-171.

34. Alikwe PCN, Elijah IO, Soladoye MO (2014) Evaluation of the Proximate Mineral, Phytochemical and Amino Acid Composition of Bidens Pilosa as Potential Feed/Feed Additive for Non-Ruminant Livestock. Animal and Veterinary Sciences, 2: 18-21.

35. Antia BS, Akpan EJ, Okon PA, Umoren IU (2006) Comparison of the nutritive value and biological activities of the acetone, methanol and water extract of the 
Citation: Mzengereza K, Msiska OV, Kapute F, Kang'ombe J, Singini W, et al. (2014) Nutritional Value of Locally Available Plants with Potential for Diets of Tilapia Rendalli in Pond Aquaculture in NkhataBay, Malawi. J Aquac Res Development 5: 265. doi:10.4172/2155-9546.1000265

leaves of Bidens pilosa and chenopodiumm album. Pakistan Journal Nutrition 5: $166-178$

36. Dongmeza E, Steinbronn S, Francis G, Focken U, Becker K (2008) Investigations on the nutrient and antinutrients content of typical plants used as fish feed in small scale aquaculture in the mountainous regions of Northern Vietnam. Animal Feed Science and Technology, 149:162-178.
37. Abowei JFN, Ekubo AT (2011) A Review of Conventional and Unconventional Feeds in Fish Nutrition, British Journal of Pharmacology and Toxicology 2: 179191.

38. Lim C, Mediha Y, Phillip K (2009) Global Aquaculture Alliance. Aquatic Animal Health Research Lab, 990 Wire Road, Auburn, Alabama, USA.

39. Lola A (2009) The Effect of Boiling on the Nutrients and Anti-Nutrients in Two non Conventional Vegetables. Pakistan Journal of Nutrition 8: 1430-1433. 